\title{
An Assessment of the Attitudes of Three Big Football Teams' Supporters in Turkey towards Fanaticism
}

\author{
Mehmet Yalcin Tasmektepligil \\ Yasar Dogu Faculty of Sports Sciences, Ondokuz Mayis University, Turkey
}

Copyright $\mathrm{C} 2016$ by authors, all rights reserved. Authors agree that this article remains permanently open access under the terms of the Creative Commons Attribution License 4.0 International License

\begin{abstract}
The purpose of this study is to evaluate the attitudes of the spectators of the three big football teams in Turkey towards being a supporter. The study was conducted on a total of 429 individuals who were members of the supporters unions of Beşiktaş, Galatasaray and Fenerbahçe teams, current champions of Turkey's Spor Toto Super League, which have a past of longer than one hundred years, or who were just supporters of these teams. The sample was chosen through the random sampling method. The 'Football Supporter Fanaticism Scale' (FSFS) developed by Taşmektepligil et al., was used in the study. The results of the study showed that attitudes about being a supporter showed significant differences in terms of the variables of 'gender, marital status, occupation, income, being in a supporter group and stand in the stadium'. It can be said that fanatic attitudes differed significantly among male, single individuals who had low incomes, who watched games behind the goal posts and who were in a supporter group. It was found that very few of the individuals who were included in this study were fanatics $(4.2 \% ; \mathrm{n}=18)$, while a great majority were supporters $(30.8 \% ; \mathrm{n}=132)$ and spectators $(65.0 \% ; \mathrm{n}=279)$. Of fanatic supporters, $1.6 \%$ $(\mathrm{n}=7)$ were Beşiktaş supporters, while $0.7 \%(\mathrm{n}=3)$ were Galatasaray supporters and $1.9 \%(\mathrm{n}=8)$ were Fenerbahçe supporters. As a conclusion, it can be said that there are marginal individuals among the supporters of the three big clubs although in low numbers. Thus, precautions should be taken to prevent these individuals from becoming active in supporters unions and they should be periodically educated about acceptable supporter behaviours.
\end{abstract}

Keywords Education, Fanatic, Football, Supporter

\section{Introduction}

Today, football stands out as one of the most demanded sports branches in the world with an economy of more than 150 billion euros and involving one billion people $[1,2]$. Spectators are inevitable elements of football's existence. It was reported that each game of EURO 2016 was watched on TV by 150 million people and by a total of 2.5 million people in stadiums [3]. Within this supply and demand balance, football teams need to create a devoted mass of supporters so that the teams can become a sustainable trademark and increase their incomes [4]. Thus, within the developing football market, clubs try to create values with characteristics that attract the attention of existing and potential supporters and spectators [5].

All of these can be assessed as efforts to make a great number of individuals the sympathisers of the club. Actually, these practices are activities done by all sports clubs, and they also develop the psychological and emotional connections of individuals with the team. However, at this point it is very important for individuals to stay within the legal limits of sympathising with a team and being committed to a team. Otherwise, the society can be faced with a pathological mass of spectators that can harm the social integrity instead of healthy sympathisers. As a matter of fact, this mass of spectators, commonly called fanatics, causes many threatening and disturbing events in sports activities as a result of their tendency for violence [6-8]. Thus, for sport scientists, the analysis of fanaticism in studies conducted on football spectators is always among the up-to-date subjects worth researching [9-12].

As is the case around the world, the aggressive behaviours of some of the spectators in football stadiums in Turkey are very important in terms of preventing social integrity. This condition is always on the agenda of football authorities; therefore, knowing the fanaticism levels of spectators of clubs who harm sportive activities is very important in terms of providing information to decision makers about the precautions to take before competitions. Thus, the purpose of this study is to determine the fanaticism levels of supporters of the three big football clubs (Beşiktaş, Galatasaray and Fenerbahçe) in Turkey, which have been participants of the Turkish football world for more than a century.

\section{Materials and Methods}




\subsection{Population and Sample}

The pool of this study consists of individuals who are members of the supporters unions of the three big clubs in Turkey's Spor Toto Super League or who are just supporters of these teams. One of the criteria in determining the sample size of a research is the number of parameters to be predicted by the model, being at least ten times bigger than the sample size. Some researchers have stated that in data sets that are normally distributed, it is enough for the sample size to be five times bigger than the number of items [13].

For this reason, the number of individuals included in the study (429) is more than the minimum number of samples (number of items*10,13*10=130). Thus, the sample of the study consists of a total of 429 individuals chosen randomly among supporters of Beşiktaş $(\mathrm{n}=160)$, Galatasaray $(\mathrm{n}=118)$ and Fenerbahçe $(\mathrm{n}=151)$, which made up the Turkey Spor Toto Super League during the 2014-2015 season. Of the participants, $38(8.9 \%)$ were female, while $391(91.1 \%)$ were male. The study was conducted not on normal spectator groups but on individuals, most of whom were members of supporters unions or who watched games next to these individuals in the same stands. While $62.2 \%$ $(\mathrm{n}=267)$ of these individuals were members of a supporters union, $37.8 \%(\mathrm{n}=162)$ were not members of a supporters union.

\subsection{Data Collection Tool}

In order to determine the attitudes of the sample about being a supporter, the 'Football Supporter Fanaticism Scale' (FSFS) developed by Taşmektepligil was used [14]. The scale consisted of a total of 13 items prepared in a 4-point Likert-type scale (Strongly agree $=1$, Agree $=2$, Disagree $=$ 3 , Strongly disagree $=4$ ). The first eight items of the scale, the first factor, express the supporters' 'thought and action tendencies of violence'. The last five items of the scale, the second factor, express the supporters' 'attitudes towards institutional belonging'.

The internal consistency coefficient (Cronbach's alpha) of FSFS was found to be $\alpha=0.852$. Factor analysis was conducted to test the construct validity of the scale. The factor loads of the items in the scale were found to be between 0.519 and 0.762 . It was concluded from the results of KMO (0.846) and Bartlett's test (1504.49) that the factor analysis was interpretable. According to fanaticism scale criteria, if the total scores of the individuals were between 13 and 21 , they were concluded to be 'fans', if the scores were between 22 and 30, they were concluded to be 'supporters' and if the scores were found to be between 31 and 52, they were concluded to be 'spectators'. It can be said that as the scores of both dimensions and also total scores increased, individual teams' dependence decreased.

\subsection{Data Analysis}

After the descriptive statistics of research results were conducted according to FSFS criteria, differences between the participants' genders, marital status and the state of being in a supporter group were analysed by Mann-Whitney U test, while differences between education, occupation, income and stand in the stadium were analysed by Kruskal-Wallis $\mathrm{H}$ test. In addition, the distribution of the attitudes of participants about being a supporter in terms of all these characteristics was analysed by Chi-Squared $\left(\chi^{2}\right)$ test.

\section{Results}

In this study, participants' attitudes about being a supporter were statistically analysed in terms of gender, marital status, being a member of a supporter group, education, occupation, income and stand in the stadium and significant associations were determined. The subscale scores of Football Supporter Fanaticism Scale (FSFS) for the supporters in terms of gender, marital status, being member of a supporter group, occupational status, income, the place of stand in the stadium and teams were given as sample size (n), mean with standard deviation, median, interquartile range (IQR), minimum and maximum values in Table 1-7, respectively. The results of Mann Whitney $U$ and Kruskal Wallis $\mathrm{H}$ test showed that there were the significant differences among the subscale scores of Football Supporter Fanaticism Scale (FSFS) in terms of the examined social-demographic characteristics of the supporters (Table 1-7). Since an individual's attitudes about being supporters were not found to be significant in terms of level of education, their tables are not presented.

Table 1. Mann Whitney $U$ test results of attitudes about being a supporter in terms of gender

\begin{tabular}{|c|c|c|c|c|c|c|c|c|}
\hline Dimensions & Gender & $\mathrm{n}$ & $\bar{x} \pm \mathrm{Sd}$ & Med & IQR & Min & Max & $P$ \\
\hline \multirow{2}{*}{ Institutional belonging } & Male & 391 & $11.37 \pm 4.26$ & 11.00 & 8.00 & 6.00 & 24.00 & \multirow{2}{*}{0.017} \\
\hline & Female & 38 & $14.29 \pm 3.25$ & 14.00 & 4.25 & 8.00 & 21.00 & \\
\hline \multirow{2}{*}{$\begin{array}{c}\text { Thought and action tendencies of } \\
\text { violence }\end{array}$} & Male & 391 & $22.12 \pm 4.29$ & 22.00 & 6.00 & 7.00 & 28.00 & \multirow{2}{*}{$<0.001$} \\
\hline & Female & 38 & $23,87 \pm 4.36$ & 26.00 & 6.25 & 14.00 & 28.00 & \\
\hline Total score & Female & 38 & $38,16 \pm 6.10$ & 38.00 & 9.75 & 26.00 & 49.00 & $<0.001$ \\
\hline
\end{tabular}

In the study, spectators' attitudes about being a supporter showed statistically significant difference in terms of gender in both dimensions and in total score. According to results, it can be said that women's belonging is lower (Table 1). 
Table 2. Mann Whitney U test results of attitudes about being a supporter in terms of marital status

\begin{tabular}{|c|c|c|c|c|c|c|c|c|}
\hline Dimensions & Marital Status & $\mathrm{n}$ & $\bar{x} \pm \mathrm{Sd}$ & Med & IQR & Min & Max & $P$ \\
\hline \multirow{2}{*}{ Institutional belonging } & Married & 231 & $13.18 \pm 3.77$ & 14.00 & 6.00 & 6.00 & 24.00 & \multirow{2}{*}{$<0.001$} \\
\hline & Single & 198 & $9.82 \pm 4.08$ & 8.00 & 7.00 & 6.00 & 21.00 & \\
\hline \multirow{2}{*}{$\begin{array}{c}\text { Thought and action tendencies of } \\
\text { violence }\end{array}$} & Married & 231 & $23.25 \pm 4.22$ & 24.00 & 6.00 & 7.00 & 28.00 & \multirow{2}{*}{$<0.001$} \\
\hline & Single & 198 & $21.14 \pm 4.17$ & 21.00 & 6.00 & 7.00 & 28.00 & \\
\hline \multirow{2}{*}{ Total score } & Married & 231 & $36.43 \pm 6.60$ & 37.00 & 11.00 & 18.00 & 52.00 & \multirow{2}{*}{$<0.001$} \\
\hline & Single & 198 & $30.95 \pm 7.05$ & 30.00 & 10.00 & 13.00 & 49.00 & \\
\hline
\end{tabular}

There is significant difference in spectators' attitudes about being a supporter in terms of marital status. Single spectators show more belonging when compared with married viewers (Table 2).

Table 3. Mann Whitney $U$ test results of attitudes about being a supporter in terms of being member of a supporter group

\begin{tabular}{|c|c|c|c|c|c|c|c|c|}
\hline Dimensions & $\begin{array}{l}\text { Being member of a } \\
\text { supporter group }\end{array}$ & $\mathrm{n}$ & $\bar{x} \pm \mathrm{Sd}$ & Med & IQR & Min & Max & $P$ \\
\hline \multirow{2}{*}{ Institutional belonging } & Yes & 267 & $10.60 \pm 3.96$ & 10.00 & 7.00 & 6.00 & 23.00 & \multirow{2}{*}{$<0.001$} \\
\hline & No & 162 & $13.33 \pm 4.20$ & 14.00 & 6.00 & 6.00 & 24.00 & \\
\hline \multirow{2}{*}{$\begin{array}{l}\text { Thought and action } \\
\text { tendencies of violence }\end{array}$} & Yes & 267 & $21.64 \pm 4.14$ & 22.00 & 6.00 & 7.00 & 28.00 & \multirow{2}{*}{$<0.001$} \\
\hline & No & 162 & $23.32 \pm 4.28$ & 24.00 & 6.00 & 7.00 & 28.00 & \\
\hline \multirow{2}{*}{ Total score } & Yes & 267 & $32.24 \pm 7.01$ & 32.00 & 10.00 & 13.00 & 51.00 & \multirow{2}{*}{$<0.001$} \\
\hline & No & 162 & $36.65 \pm 7.04$ & 37.00 & 10.00 & 16.00 & 52.00 & \\
\hline
\end{tabular}

As can be seen from Table 3, being member of a supporter group increases individuals' belonging significantly.

Table 4. Kruskal Wallis $H$ test results of attitudes about being a supporter in terms of occupation

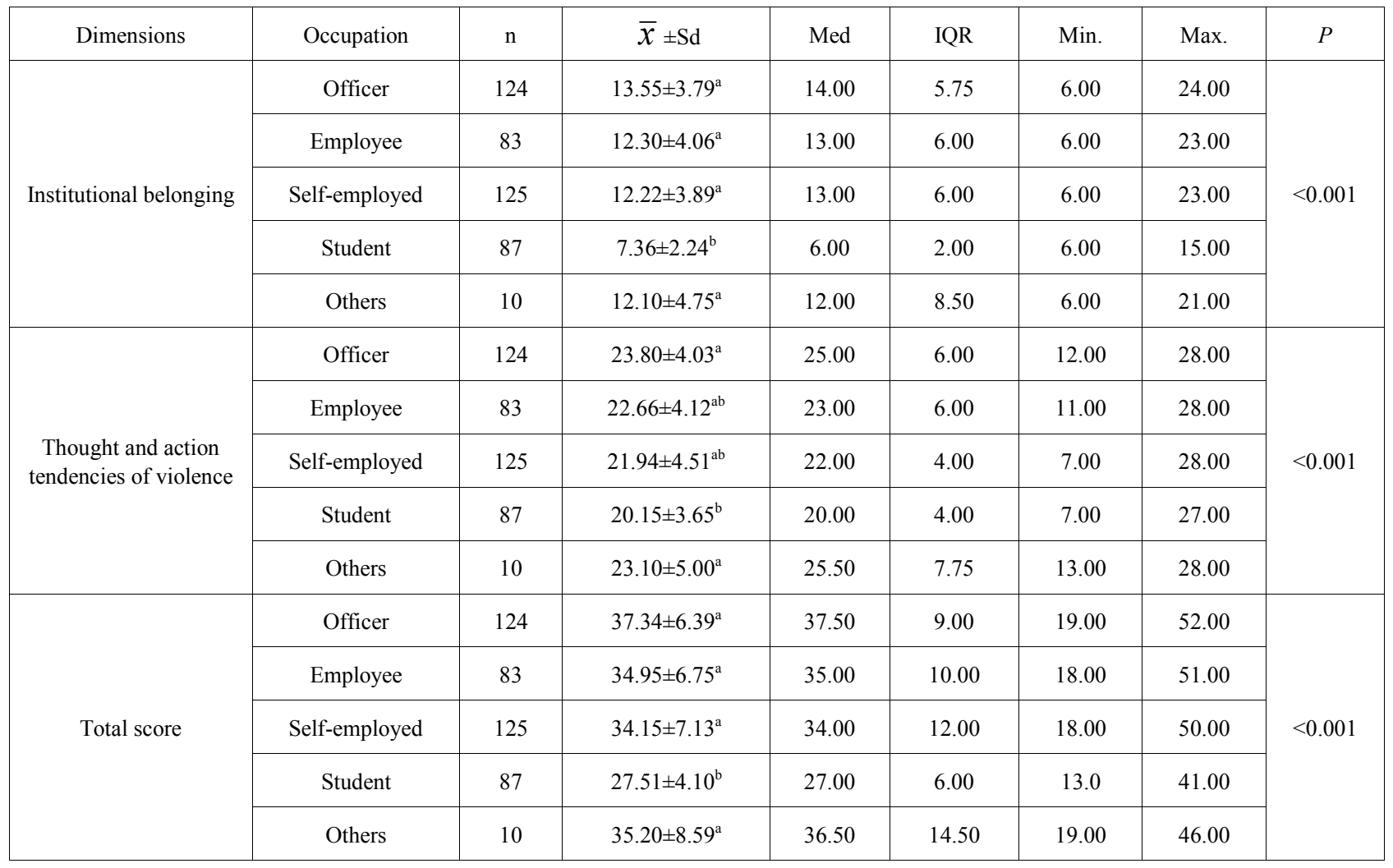

The significant difference in participants' FSFS scale is caused by student groups. No significance was found in other occupation groups (Table 4) 
Table 5. Kruskal Wallis $\mathrm{H}$ test results of attitudes about being a supporter in terms of income

\begin{tabular}{|c|c|c|c|c|c|c|c|c|}
\hline Dimensions & Income & $\mathrm{n}$ & $\bar{x} \pm \mathrm{Sd}$ & Med & IQR & Min. & Max. & $P$ \\
\hline \multirow{3}{*}{ Institutional belonging } & $\geq 1000 \mathrm{TL}$ & 90 & $8.16 \pm 3.42^{c}$ & 6.00 & 3.00 & 6.00 & 22.00 & \multirow{3}{*}{$<0.001$} \\
\hline & $1001-2000 \mathrm{TL}$ & 171 & $11.64 \pm 3.98^{\mathrm{b}}$ & 11.00 & 7.00 & 6.00 & 21.00 & \\
\hline & $\geq 2001 \mathrm{TL}$ & 168 & $13.48 \pm 3.76^{\mathrm{a}}$ & 14.00 & 5.00 & 6.00 & 24.00 & \\
\hline \multirow{3}{*}{$\begin{array}{l}\text { Thought and action } \\
\text { tendencies of violence }\end{array}$} & $\geq 1000 \mathrm{TL}$ & 90 & $19.94 \pm 3.73^{\mathrm{b}}$ & 20.00 & 4.00 & 7.00 & 28.00 & \multirow{3}{*}{$<0.001$} \\
\hline & $1001-2000 \mathrm{TL}$ & 171 & $22.30 \pm 4.13^{\mathrm{a}}$ & 22.00 & 6.00 & 9.00 & 28.00 & \\
\hline & $\geq 2001 \mathrm{TL}$ & 168 & $23.50 \pm 4.32^{\mathrm{a}}$ & 25.00 & 6.00 & 7.00 & 28.00 & \\
\hline \multirow{3}{*}{ Total score } & $\geq 1000 \mathrm{TL}$ & 90 & $28.10 \pm 6.18^{c}$ & 27.00 & 6.25 & 13.00 & 48.00 & \multirow{3}{*}{$<0.001$} \\
\hline & $1001-2000 \mathrm{TL}$ & 171 & $33.94 \pm 6.38^{b}$ & 34.00 & 9.00 & 18.00 & 49.00 & \\
\hline & $\geq 2001 \mathrm{TL}$ & 168 & $36.98 \pm 6.96^{\mathrm{a}}$ & 38.00 & 9.00 & 19.00 & 52.00 & \\
\hline
\end{tabular}

$\mathrm{TL}=$ Turkish Lira

The results of the study show statistical difference between FSFS scores in terms of income. As the level of income decreases, FSFS scores also decrease (Table 5).

Table 6. Kruskal Wallis $\mathrm{H}$ test results of attitudes about being a supporter in terms of the place of stand in the stadium

\begin{tabular}{|c|c|c|c|c|c|c|c|c|}
\hline Dimensions & The place of stand in the stadium & $\mathrm{n}$ & $\bar{x} \pm \mathrm{Sd}$ & Med & IQR & Min. & Max. & $P$ \\
\hline \multirow{3}{*}{ Institutional belonging } & Bleacher & 115 & $12.36 \pm 3.73^{\mathrm{a}}$ & 13.00 & 6.00 & 6.00 & 22.00 & \multirow{3}{*}{$<0.001$} \\
\hline & Grandstand & 149 & $13.05 \pm 4.28^{\mathrm{a}}$ & 14.00 & 6.50 & 6.00 & 24.00 & \\
\hline & Goal post back & 165 & $9.84 \pm 3.96^{\mathrm{b}}$ & 8.00 & 7.00 & 6.00 & 19.00 & \\
\hline \multirow{3}{*}{$\begin{array}{c}\text { Thought and action tendencies of } \\
\text { violence }\end{array}$} & Bleacher & 115 & $22.39 \pm 4.01^{\mathrm{ab}}$ & 22.00 & 7.00 & 11.00 & 28.00 & \multirow{3}{*}{$<0.001$} \\
\hline & Grandstand & 149 & $23.36 \pm 4.61^{\mathrm{a}}$ & 25.00 & 6.00 & 7.00 & 28.00 & \\
\hline & Goal post back & 165 & $21.21 \pm 4.02^{\mathrm{b}}$ & 21.00 & 5.00 & 7.00 & 28.00 & \\
\hline \multirow{3}{*}{ Total score } & Bleacher & 115 & $34.75 \pm 6.41^{\mathrm{a}}$ & 35.00 & 10.00 & 18.00 & 49.00 & \multirow{3}{*}{$<0.001$} \\
\hline & Grandstand & 149 & $36.42 \pm 7.60^{\mathrm{a}}$ & 37.00 & 13.00 & 19.00 & 52.00 & \\
\hline & Goal post back & 165 & $31.05 \pm 6.73^{\mathrm{b}}$ & 31.00 & 10.00 & 13.00 & 46.00 & \\
\hline
\end{tabular}

Statistically significant difference was found between participants' FSFS scale scores in terms of the place of stand in the stadium. The spectators at goal post back had lower scores than the others (Table 6). On the other hand, the results of the study showed that Fenerbahçe and Beşiktaş supporters were more devoted to their teams (Table 7).

Table 7. Kruskal Wallis $\mathrm{H}$ test results in terms of supporters' scores from the scale

\begin{tabular}{|c|c|c|c|c|c|c|c|}
\hline Teams & $\mathrm{n}$ & $\bar{x} \pm \mathrm{Sd}$ & Med & IQR & Min & Max & $P$ \\
\hline Beşiktaş & 160 & $33.26 \pm 7.44_{\mathrm{b}}$ & 33.00 & 11.00 & 18.00 & 51.00 & \\
\hline Galatasaray & 118 & $36.16 \pm 7.26_{\mathrm{a}}$ & 37.00 & 11.00 & 18.00 & 52.00 & $<0.001$ \\
\hline Fenerbahçe & 151 & $32.80 \pm 6.92 \mathrm{~b}$ & 34.00 & 10.00 & 13.00 & 52.00 & \\
\hline
\end{tabular}

The distributions of the social-demographic characteristics of the supporters in terms of gender, marital status, occupational status, income, the place of stand in the stadium, being member of a supporter group and teams were given as sample size (n) and percentage (\%) in Table 8-14, respectively. The results of chi-square analyses showed that the status of audience statistically depends on the gender, marital status, occupational status, income, the place of stand in the stadium, being member of a supporter group and teams of the supporters (Table 8-14).

Table 8. Distribution of attitudes about being a supporter in terms of gender

\begin{tabular}{|c|c|c|c|c|c|c|}
\hline \multirow{3}{*}{ Status of audience } & \multicolumn{4}{|c|}{ Gender } & \multicolumn{2}{|c|}{ Total } \\
\hline & \multicolumn{2}{|c|}{ Male } & \multicolumn{2}{|c|}{ Female } & \multirow{2}{*}{$\mathrm{n}$} & \multirow{2}{*}{$\%$} \\
\hline & $\mathrm{n}$ & $\%$ & $\mathrm{n}$ & $\%$ & & \\
\hline Fanatic & 18 & 4.6 & 0 & 0 & 18 & 4.2 \\
\hline Team supporter & 128 & 32.7 & 4 & 10.5 & 132 & 30.8 \\
\hline Spectator & 245 & 62.7 & 34 & 89.5 & 279 & 65.0 \\
\hline Total & 391 & 91.1 & 38 & 8.9 & 429 & 100.0 \\
\hline
\end{tabular}

$\chi^{2}=11.131 ; P=0.004$

No fan groups were found among women. In addition, it was found that a great majority of women ( $85 \%)$ were only spectators (Table 8). 
Table 9. Distribution of attitudes about being a supporter in terms of marital status

\begin{tabular}{|c|c|c|c|c|c|c|}
\hline \multirow{3}{*}{ Status of audience } & \multicolumn{4}{|c|}{ Marital status } & \multicolumn{2}{|c|}{ Total } \\
\hline & \multicolumn{2}{|c|}{ Married } & \multicolumn{2}{|c|}{ Single } & \multirow{2}{*}{$\mathrm{n}$} & \multirow{2}{*}{$\%$} \\
\hline & $\mathrm{n}$ & $\%$ & $\mathrm{~N}$ & $\%$ & & \\
\hline Fanatic & 4 & 1.7 & 14 & 7.1 & 18 & 4.2 \\
\hline Team supporter & 42 & 18.2 & 90 & 45.5 & 132 & 30.8 \\
\hline Spectator & 185 & 80.1 & 94 & 47.5 & 279 & 65.0 \\
\hline Total & 231 & 53.8 & 198 & 46.2 & 429 & 100.0 \\
\hline
\end{tabular}

$\chi^{2}=50.451 ; P<0.001$

According to the results of the study, the single were more devoted to their teams (fans and team supporters) when compared with the married (Table 9).

Table 10. Distribution of attitudes about being a supporter in terms of occupational status

\begin{tabular}{|c|c|c|c|c|c|c|c|c|c|c|c|c|}
\hline \multirow{3}{*}{ Status of audience } & \multicolumn{10}{|c|}{ Occupational status } & \multicolumn{2}{|c|}{ Total } \\
\hline & \multicolumn{2}{|c|}{ Officer } & \multicolumn{2}{|c|}{ Employee } & \multicolumn{2}{|c|}{ Self-employed } & \multicolumn{2}{|c|}{ Student } & \multicolumn{2}{|c|}{ Others } & \multirow{2}{*}{$\mathrm{n}$} & \multirow{2}{*}{$\%$} \\
\hline & $\mathrm{n}$ & $\%$ & $\mathrm{n}$ & $\%$ & $\mathrm{n}$ & $\%$ & $\mathrm{~N}$ & $\%$ & $\mathrm{n}$ & $\%$ & & \\
\hline Fanatic & 1 & 0.8 & 3 & 3.6 & 6 & 4.8 & 7 & 8.0 & 1 & 10.0 & 18 & 4.2 \\
\hline Team supporter & 17 & 13.7 & 19 & 22.9 & 33 & 26.4 & 61 & 70.1 & 2 & 20.0 & 132 & 30.8 \\
\hline Spectator & 106 & 85.5 & 61 & 73.5 & 86 & 68.8 & 19 & 21.8 & 7 & 70.0 & 279 & 65.0 \\
\hline Total & 124 & 28.9 & 83 & 19.3 & 125 & 29.1 & 87 & 20.3 & 10 & 2.3 & 429 & 100.0 \\
\hline
\end{tabular}

$\chi^{2}=99.931 ; P<0.001$

Students' FSFS scored were lower than those of other occupations. In other words, it can be seen that fanaticism attitude dependent on the variable of being a student(Table 10)

Table 11. Distribution of attitudes about being a supporter in terms of income

\begin{tabular}{|c|c|c|c|c|c|c|c|c|}
\hline \multirow{3}{*}{ Status of audience } & \multicolumn{6}{|c|}{ Income status } & \multicolumn{2}{|c|}{ Total } \\
\hline & \multicolumn{2}{|c|}{$\geq 1000 \mathrm{TL}$} & \multicolumn{2}{|c|}{$1001-2000 \mathrm{TL}$} & \multicolumn{2}{|c|}{$\geq 2001 \mathrm{TL}$} & \multirow{2}{*}{$\mathrm{n}$} & \multirow{2}{*}{$\%$} \\
\hline & $\mathrm{n}$ & $\%$ & $\mathrm{n}$ & $\%$ & $\mathrm{n}$ & $\%$ & & \\
\hline Fanatic & 8 & 8.9 & 5 & 2.9 & 5 & 3.0 & 18 & 4.2 \\
\hline Team supporter & 60 & 66.7 & 44 & 25.7 & 28 & 16.7 & 132 & 30.8 \\
\hline Spectator & 22 & 24.4 & 122 & 71.3 & 135 & 80.4 & 279 & 65.0 \\
\hline Total & 90 & 21.0 & 171 & 39.9 & 168 & 39.2 & 429 & 100.0 \\
\hline
\end{tabular}

$\chi^{2}=85.853 ; P<0.001$

Similarly, there is a dependency between income and FSFS scale scores. As income decreases, fanatic attitudes increase (Table 11).

Table 12. Distribution of attitudes about being a supporter in terms of the place of stand in the stadium

\begin{tabular}{|c|c|c|c|c|c|c|c|c|}
\hline \multirow{3}{*}{ Status of audience } & \multicolumn{6}{|c|}{ The place of stand in the stadium } & \multicolumn{2}{|c|}{ Total } \\
\hline & \multicolumn{2}{|c|}{ Bleacher } & \multicolumn{2}{|c|}{ Grandstand } & \multicolumn{2}{|c|}{ Goal post back } & \multirow{2}{*}{$\mathrm{n}$} & \multirow{2}{*}{$\%$} \\
\hline & $\mathrm{n}$ & $\%$ & $\mathrm{n}$ & $\%$ & $\mathrm{n}$ & $\%$ & & \\
\hline Fanatic & 3 & 2.6 & 4 & 2.7 & 11 & 6.7 & 18 & 4.2 \\
\hline Team supporter & 28 & 24.3 & 34 & 22.8 & 70 & 42.4 & 132 & 30.8 \\
\hline Spectator & 84 & 73.0 & 111 & 74.5 & 84 & 50.9 & 279 & 65.0 \\
\hline Total & 115 & 26.8 & 149 & 34.7 & 165 & 38.5 & 429 & 100.0 \\
\hline
\end{tabular}

$\chi^{2}=24.036 ; P<0.001$

The place of stand causes a change in individuals' FSFS scores. The scores of spectators at the goal post back were found to be lower (Table 12). 
Table 13. Distribution of attitudes about being a supporter in terms of being member of a supporter group

\begin{tabular}{|c|c|c|c|c|c|c|}
\hline \multirow{3}{*}{ Status of audience } & \multicolumn{4}{|c|}{ Being member of a supporter group } & \multicolumn{2}{|c|}{ Total } \\
\hline & \multicolumn{2}{|c|}{ Yes } & \multicolumn{2}{|c|}{ No } & \multirow{2}{*}{$\mathrm{n}$} & \multirow{2}{*}{$\%$} \\
\hline & $\mathrm{n}$ & $\%$ & $\mathrm{n}$ & $\%$ & & \\
\hline Fanatic & 13 & 4.9 & 5 & 3.1 & 18 & 4.2 \\
\hline Team supporter & 107 & 40.1 & 25 & 15.4 & 132 & 30.8 \\
\hline Spectator & 147 & 55.1 & 132 & 81.5 & 279 & 65.0 \\
\hline Total & 267 & 62.2 & 162 & 37.8 & 429 & 100.0 \\
\hline
\end{tabular}

$\chi^{2}=31.488 ; P<0.001$

Table 14. Distribution of spectators in teams in terms of their status

\begin{tabular}{|c|c|c|c|c|c|c|c|c|}
\hline \multirow{2}{*}{ Teams } & \multicolumn{9}{|c|}{ Status of audience } \\
\cline { 2 - 10 } & Fanatic (13-21 point) & \multicolumn{2}{|c|}{ Supporter (22-30) } & \multicolumn{2}{|c|}{ Spectator (31-52) } & \multicolumn{2}{c|}{ Total } \\
\cline { 2 - 9 } & $\mathrm{n}$ & $\%$ & $\mathrm{n}$ & $\%$ & $\mathrm{n}$ & $\%$ & $\mathrm{n}$ & $\%$ \\
\hline Beşiktaş & 7 & 4,4 & 57 & 35,6 & 96 & 60,0 & 160 & 37,3 \\
\hline Galatasaray & 3 & 2,5 & 24 & 20,3 & 91 & 77,1 & 118 & 27,5 \\
\hline Fenerbahçe & 8 & 5,3 & 51 & 33,8 & 92 & 60,9 & 151 & 35,2 \\
\hline Total & 18 & 4,2 & 132 & 30,8 & 279 & 65,0 & 429 & 100,0 \\
\hline
\end{tabular}

$\chi^{2}=10.725 ; P<0.030$ dependency rate $\% 15,62$ status of audience varies depending on the teams.

In the study, another variable that determines individuals' attitudes about being a supporter is being member of a supporter group. According to these results, being member of a supporter group strengthens belonging to a team (Table 13).

In the study, changes were found in three big clubs' spectators' feelings of devotion to the team. Fenerbahçe and Beşiktaş supporters were found to have lower scores than Galatasaray supporters (Table 14).

\section{Discussion}

Spectators are inevitable elements of football's existence. Spectators of football are both the guarantee of the economic presence of football companies with their supporter activities and they also increase the possibility of the realisation of their purposes within the television and advertisement industries. Thus, while football viewers are psychologically satisfied, discharged, relaxed, rested and amused through the help of their supporter activities, they also contribute to the development of the football sector [15].

While the rules of economics apply during the process, sometimes uncontrolled and detrimental rivalries develop and spectators play a basic role in the emergence of many negative events. In fact, supporters are born and raised in an atmosphere imposed upon them by the place and the time in which they live. If these conditions can be sufficiently controlled, marginal supporter behaviours can be relatively prevented. In order to be able to prevent aggressive behaviours of supporters, primarily media and referees, footballers, supporters, unions and club/federation authorities and the state need to work together [8].

If being a supporter means supporting a team within acceptable limits with no extremism, it can be seen as a necessary aspect of socialising and it should even be encouraged. However, if the feelings of being a supporter reach the level of fanaticism and begin to hurt other people, this should be taken as a sign that sports has become not a tool but a purpose in the development of individuals and the society [16]. In this respect, when being devoted to a sports club becomes fanaticism, this may cause serious behavioural disorders and social problems. Although researchers analyse many different aspects of supporters, one of the predominant topics of interest remains supporter aggression. Thus, sport scientists have focused on the aggressiveness and violent reactions of supporters $[17,18]$.

In this study, while no statistical difference was found in the state of being a supporter in terms of the variable of education, significant difference was found in both dimension scores and total score in terms of the variables of gender and marital status (Table 1, Table 2). It can be said that the state of being a supporter varies in terms of gender and marital status (Table 8, Table 9). Here it can be said that men are more devoted to their teams than women while married men are more devoted than single men. Likewise, the average scores of spectators in a supporter group are significantly lower when compared with others. While this result does not mean that being a member of a supporter group causes individuals to become fanatics, it reinforces the idea that in time it can lead individuals to develop fanatical attitudes (Table 3 ). Thus, attitudes of individuals about being a supporter can differ significantly based on the variable of being a member of a supporter group (Table 13).

At the same time, it was found that attitudes about being a supporter showed statistically significant differences in terms of the variables of occupation and income. In the 
occupation group, the students with the lowest score are significantly different in the sub dimension of 'action tendencies of violence' except for the employee and self-employed group (Table 4). Here, it can be understood that fanatic groups are mostly students, followed by the self-employed group (Table 10). Thus, fanaticism shows a significant change in terms of the state of being a student. Similarly, spectators' attitudes about being a supporter also differ according to the status of income. Individuals with the lowest income were found to get the lowest score from the scale (Table 5). This means that as the levels of income decrease, spectators begin to tend to move towards fanaticism from being a supporter (Table 11). Some researchers have reported significant increases in the tendencies of participating in events as individuals' economic levels decreased [19-22].

According to the study, another parameter that influences the attitudes of individuals about being a supporter is the place of the stand in the stadium (Table 6). Fanaticism differs according to the place from which the game is viewed (Table 12). In fact, individuals usually comply with commonly accepted standards; however, they do not behave in that manner when they are in a group [23]. In this respect, the behaviours of supporters in a group are of primary importance, and it is important to educate these supporters so that they can adopt acceptable behaviour patterns.

This study determined the statistical differences between the attitudes of spectators from three long-established clubs (Table 7). Here, it can be stated that Beşiktaş and Fenerbahçe supporters are more devoted to their teams when compared with Galatasaray supporters. Thus, the characteristics of spectators differ according to teams and they contain a $15 \%$ level of devotion (Table 14).

In conclusion, it is well known that football is one of the most common and most popular sports in Turkey; also, in comparison with other sports, it has the largest number of fans and spectators. Very few spectators from three respectable, long-established clubs can be defined as being fanatics. However, these rates can always increase due to interaction between groups. The condition of fanaticism could be attributed to the social learning theory that values the environmental factor in the cognitive process of aggression. The presented results may be of help to football teams' administrators to control the incidence of fanaticism.

\section{REFERENCES}

[1] Akşar T (2005). Endüstriyel Futbol. 1.Basım, Literatür Yayınları. İstanbul.

[2] Talimciler A (2008). Futbol değil iş: endüstriyel futbol, İletişim Kuram ve Araştırma Dergisi. 26: 89-114. http://www.irfanerdogan.com/dergiweb2008/26/3ahmet.pdf

[3] Akşar T (2016). Euro 2016'da Türkiye ne kazanacak? Fransa ne kazanacak? Retrieved August 12, 2016, from http://t24.com.tr/yazarlar/tugrul-aksar/euro-2016da-turkiye-n e-kazanacak-fransa-ne kazanacak, 14805

[4] Kazançoğlu İ, Baybars M (2016). Licensed sports merchandise perceived value components and their relationship with purchase intention: investigation of top three soccer clubs of Turkey, Doğuş University Journal. 17(1):51-66.

http://journal.dogus.edu.tr/index.php/duj/article/view/918/pd f

[5] Gencer T, Aycan A (2008). An investigation on variables affecting the spectator decision to attend professional soccer games in Turkey. Ege Academic Review. 8(2):771-783. http://www.onlinedergi.com/MakaleDosyalari/51/PDF2008_ 2_17.pdf

[6] Shields DL, Bredemeier BL, LaVoi NM, Power CF (2005). The sport behavior of youth, parents, and coaches: The good, the bad, and the ugly. Journal of Research in Character Education, 3, 43-59. https://www.highbeam.com/doc/1P3-10 40202871.html

[7] Shields DL, LaVoi NM, Bredemeier BL, Power FC (2007). Predictors of poor sportspersonship in youth sports: Personal attitudes and social influences. Journal of Sport \& Exercise Psychology. 29(6):747-762.

https://www.stlawu.edu/library/system/files/course_readings /Shields_Predictors_of_poor.pdf

[8] Koçer M (2012). Mapping violence and hooliganism tendencies of football fans who are registered to football associations: the sample of Kayseri. Journal of The Institute Social Sciences. 32(1): 111-135. http://sbedergi.erciyes.edu.t r/sayi_32/7-111-136.pdf

[9] Wann DL, Schrader MP, Carlson JD (2000). The verbal aggression of sport spectators: A comparison of hostile and instrumental motives. International Sports Journal. 4(2):56-63.

[10] Wann DL, Melnick MJ, Russell GW, Pease DG (2001). Sport Fans: The Psychology and Social Impact of Spectators. New York: Routledge.

[11] Heydarinejad S, Gholami S (2012). Identification of factors of aggression incidence among football spectators in Khuzestan. Studies in Physical Culture and Tourism. 19(1):37-41. http://www.wbc.poznan.pl/Content/217192/10_Heydarinejad _37_41.pdf

[12] Kosiewicz J (2015).New Paradigm: Science on Aggression with Sport in the Background. Physical Culture and Sport. Studies and Research. 67(1):65-75. DOI:

10.1515/pcssr-2015-0022 http://www.degruyter.com/downlo adpdf/j/pcssr.2015.67.issue-1/pcssr-2015-0022/pcssr-2015-0 022.xml

[13] Kline RB (2005). Principles Practice of Structural Equation Modeling $\left(2^{\text {nd }}\right.$. ed.). New York: Guilford Press.

[14] Tasmektepligil MY, Cankaya S, Tunc T (2015). Fanaticism Scale for Football Fans. Journal of Sports and Performance Researches. 6(1):41-49. DOI No: 10.17155/spd.73408 http://dergipark.ulakbim.gov.tr/omuspd/article/view/500007 $8177 / 5000081317$

[15] Erdoğan İ (2008). Futbol ve futbolu inceleme üzerine. Gazi Üniversitesi İletişim Fakültesi. İletişim Kuram ve Araştırma Dergisi. 26: 1-58. http://www.ilet.gazi.edu.tr/posts/download ?id $=13823$ 
[16] Tunç T, Karakaş F, Çankaya S, Taşmektepligil MY (2013). An Evaluation of the Attitudes and Behavior of the Students Samsun Ondokuz Mayis Vocational Police High School about Being a Supporter Based on Football Fanaticism Scale. Tolerance in Violence Out, European Commission TAIEX, Uluslararası Sporda Şiddetin Temelleri ve Önlenmesi Yönündeki Stratejiler Sempozyumu, pp. 270-78, Samsun/Turkey.

[17] Theodorakis ND, Dimmock J, Wann D, Barlas A (2010). Psychometric evaluation of the team identification scale among Greek sport fans: A cross-validation approach. European Sport Management Quarterly. 10(3):289-305. http://dx.doi.org/10.1080/16184741003770180

[18] Wann DL, Weaver S, Belva B, Ladd S, Armstrong S (2015). Investigating the impact of team identification on the willingness to commit verbal and physical aggression by youth baseball spectators. Journal of Amateur Sport. 1(1):1-28. https://journals.ku.edu/index.php/jams/article/vie $\mathrm{w} / 4919 / 4458$

[19] K1lcigil E (2003). Psycho-social aspects of reactions by football fans concerning violence. Ankara Üniversitesi Spor Bilimleri Fakültesi. Spormetre.1(1):21-29. http://dergiler.ank ara.edu.tr/dergiler/17/346/3597.pdf

[20] Bahadır Z (2006). Futbol Seyircisinin Sosyo-Ekonomik Kültürel Yapısının Şiddet Eylemine Etkisi (Konyaspor Örneği). Niğde Üniversitesi, Sosyal Bilimler Enstitüsü, Beden Eğitimi ve Spor Ana Bilim Dalı, Yüksek Lisans Tezi. Niğde.

[21] Kurtiç N (2006). Futbol Seyircisini Saldırganlığa İten Psiko-Sosyo Nedenler (Sakarya İli Örneği). Sakarya Üniversitesi, Sosyal Bilimler Enstitüsü, Beden Eğitimi ve Spor Öğretmenliği Ana Bilim Dalı, Yüksek Lisans Tezi, Sakarya.

[22] Yıldız M, Fişekçioğlu ĠB, Çağlayan HS, Tekin M, Şirin EF, Akyüz M (2007). The effect of football spectators' social-economic structure on violence (Sample of Karamanspor). Erzincan Journal of Education Faculty. 9(2):145-158.http://eefdergi.erzincan.edu.tr/article/view/100 6000713

[23] Ramazanoğlu F (2012). Spectators' behaviour from the view of security forces in sport competitions, Arch Budo. 8(2):59-63. http://files.4medicine.pl/download.php?cfs_id=1 258 